\title{
Clinical, bacteriological and histopathological assessment of multibacillary leprosy cases after 1 and 2 years multidrug therapy. Preliminary communication*
}

\author{
A N B McNAIR, $\uparrow$ C R REVANKAR $\ddagger$ \& RANAPATI \\ $\dagger$ Middlesex Hospital Medical School, London; $\ddagger$ Bombay Leprosy \\ Project, Vidnyan Bhavan, 11 Purav Marg, Sion (East), Bombay 400 \\ 022, India
}

\section{Accepted for publication 2 October 1986}

\begin{abstract}
Summary Seventy-three multibacillary leprosy patients in Bombay who had completed 12 and 24 monthly doses of multidrug therapy (MDT) were subjected to clinical, bacteriological and histopathological assessment. Only one in 17 of the 12 dose group with initial Bacterial Index $(\mathrm{BI}) \geqslant 2$ was rendered smear negative. This increased to more than $50 \%$ in the 24 dose group with the same BI. A number of discrepancies were noted in the correlation between clinical, bacteriological and histopathological findings in treated cases in both the 12 and the 24 month group and the possible reasons are discussed. This report is preliminary and longterm studies on a larger scale are clearly needed for more accurate assessment, but the data so far available suggest that considerable emphasis should be given to the $\mathrm{BI}$, as the least subjective test, in deciding when to stop chemotherapy.
\end{abstract}

\section{Introduction}

The Bombay Leprosy Project began to use multidrug therapy routinely for the treatment of multibacillary leprosy following the recommendations of the World Health Organization in 1982.' The Indian Association of Leprologists (IAL) made similar recommendations ${ }^{2}$ but the drug regimens differed slightly.

In view of the importance of information pertaining to clinical, bacteriological and especially histopathological changes after different durations of multidrug therapy (MDT), a preliminary assessment of patients who had completed one and two years' treatment (12 and 24 monthly doses) was carried out under urban conditions, which have already been described. ${ }^{3}$

* This study was carried out as part of an elective period supported by LEPRA.

$\S$ Present address; 13 Oxfield Close, Berkhamstead, Herts HP4 3NE, England. 


\section{Material and methods}

The Bombay Leprosy Project (BLP) is a field-based control programme run largely by trained paramedical workers, with limited facilities available for advanced laboratory research work.

A total of 73 multibacillary (smear positive) cases were selected for the study, 28 of whom had previously received dapsone monotherapy, the remainder having had no previous treatment. Thirty were living in leprosy colonies on the outskirts of Bombay. The rest attended their nearest BLP clinics in a hospital or urban health centre.

A period of 7 weeks was spent assessing patients who had just completed 12 or 24 monthly doses of MDT. Most of these patients received the regimen recommended by the IAL, i.e. an initial course of 21 days continuous rifampicin was administered under supervision. However, patients who had a poor record of compliance or who attended clinics with inadequate facilities were given the usual WHO drug regimen (Table 1).

\section{CLINICAL ASSESSMENT}

A clinical assessment of each patient was made to assess the activity of the disease. This information was used to classify each patient's condition after MDT as 'active', 'regressing' or 'inactive' on purely clinical grounds. This was based on standard criteria for assessing the activity of the disease. ${ }^{4}$ Clinical 'inactivity' is defined as absence of signs of activity in the skin (no new lesions, extension of old lesions, erythema, infiltration, non-traumatic ulceration or persistence of nodules) and absence of activity in neural lesions (nerve tenderness or progression of anaesthesia or muscle paralysis).

This assessment was compared with the initial clinical status report available in the patient's records.

\section{BACTERIOLOGICAL ASSESSMENT}

The slit-skin smears from a minimum of four sites were taken and compared with the initial (pretreatment) BI available from the patient's records in order to determine the extent of decline of the BI over the treatment period. All originally smear positive cases were considered for the study regardless of duration of disease or previous treatment.

\section{HISTOPATHOLOGICAL ASSESSMENT}

The skin biopsy was taken using a standard 6-mm circular punch. The sample was preserved in buffered formalin and processed at the BLP laboratory. The slides were read by an independent

Table 1. Allocation of leprosy patients

\begin{tabular}{crrr}
\hline & \multicolumn{2}{c}{ Drug regimen } \\
\cline { 2 - 3 } No. doses & WHO & IAL & Total \\
\hline 12 & 7 & 15 & 22 \\
24 & 14 & 37 & 51 \\
\hline Total & 21 & 52 & 73 \\
\hline
\end{tabular}


histopathologist and the reports classified as being consistent with 'active', 'regressing' or 'inactive' disease. The criteria used were based on descriptions by Ridley. ${ }^{5}$

Finally, the correlation between the clinical, histopathological and smear status of each patient was examined.

\section{Results and discussion}

Of the 73 patients, 22 had completed 12 pulse doses and the rest had taken 24 doses.

\section{CLINICAL ASSESSMENT}

Clinical assessment showed that only 2 cases became inactive and 4 were still showing clinical activity in the 12-dose group (Table 2(a)), whereas in the 24-dose group 14 became inactive and 8 were still showing activity (Table 2(b)). This assessment was done irrespective of smear status.

\section{BACTERIOLOGICAL ASSESSMENT}

For bacteriological assessment patients were classified into 2 groups with $\mathrm{BI}<2$ and $\mathrm{BI} \geqslant 2$. Only 1 in 17 of the 12 dose group with an initial BI of $\geqslant 2$ was rendered smear negative (Table 3(a)). This increased to more than $50 \%$ of patients in the 24 dose group with the same BI and 12 out of 13 $(92 \%)$ with B I $<2$ became smear negative after 24 doses (Table 3(b)). Smear conversion rate was faster in cases with $\mathrm{BI}<2$.

\section{Table 2}

\section{(a) 12-dose group}

Total no.

of cases Active Regressing Inactive

$\begin{array}{llll}22 & 4 & 16 & 2\end{array}$

(b) 24-dose group

Total no.

of cases Active Regressing Inactive

\begin{tabular}{llll}
\hline 51 & 8 & 29 & 14 \\
\hline
\end{tabular}

Table 3

\begin{tabular}{|c|c|c|c|c|c|c|c|c|}
\hline BI & $\begin{array}{l}\text { Bef } \\
\text { Total } \\
\text { No. of } \\
\text { cases }\end{array}$ & $\begin{array}{l}\text { ore MDT } \\
\text { Cumulative } \\
\text { BI }\end{array}$ & $\begin{array}{c}\text { Mean } \\
\text { BI }\end{array}$ & $\begin{array}{c}\text { Cumulative } \\
\text { BI }\end{array}$ & $\begin{array}{c}\text { Mean } \\
\text { BI }\end{array}$ & $\begin{array}{l}\text { MDT } \\
\text { Mean } \\
\text { change } \\
\text { BI }\end{array}$ & $\begin{array}{c}\text { Mean \% } \\
\text { change } \\
\text { BI }\end{array}$ & $\begin{array}{l}\text { Number } \\
\text { negative }\end{array}$ \\
\hline \multicolumn{9}{|c|}{ (a) 12 pulse dose group } \\
\hline$<2$ & 5 & 6.05 & $1 \cdot 21$ & 1 & $0 \cdot 2$ & $1 \cdot 01$ & $86 \cdot 7$ & 4 \\
\hline$\geqslant 2$ & 17 & $52 \cdot 9$ & $3 \cdot 11$ & $33 \cdot 4$ & $1 \cdot 96$ & $1 \cdot 15$ & $38 \cdot 8$ & 1 \\
\hline \multicolumn{9}{|c|}{ (b) 24 pulse dose group } \\
\hline$<2$ & 13 & $12 \cdot 4$ & $0 \cdot 95$ & $0 \cdot 33$ & $0 \cdot 019$ & $0 \cdot 931$ & $94 \cdot 9$ & $12(92 \%)$ \\
\hline$\geqslant 2$ & 38 & 125 & $3 \cdot 29$ & $36 \cdot 6$ & $0 \cdot 962$ & $2 \cdot 33$ & $73 \cdot 8$ & $20(53 \%)$ \\
\hline
\end{tabular}


Table 4. Number smear negative after MDT

\begin{tabular}{|c|c|c|c|c|c|c|}
\hline \multirow{2}{*}{$\begin{array}{l}\text { No. of } \\
\text { doses }\end{array}$} & \multirow[b]{2}{*}{ BI } & \multirow{2}{*}{$\begin{array}{l}\text { No. of } \\
\text { negative } \\
\text { cases }\end{array}$} & \multicolumn{3}{|c|}{$\begin{array}{l}\text { No. of previous } \\
\text { negative smears }\end{array}$} & \multirow{2}{*}{$\begin{array}{c}\text { No. with } 3 \\
\text { negative smears } \\
\text { and clinically } \\
\text { inaciive }\end{array}$} \\
\hline & & & 0 & 1 & 2 & \\
\hline \multirow{2}{*}{12} & $<2$ & 4 & 3 & 0 & 1 & 0 \\
\hline & $\geqslant 2$ & 1 & 1 & 0 & 0 & 0 \\
\hline \multirow{2}{*}{24} & $<2$ & 12 & 3 & 3 & 6 & 4 \\
\hline & $\geqslant 2$ & 20 & 9 & 4 & 7 & 3 \\
\hline Total & & 37 & 16 & 7 & 14 & 7 \\
\hline
\end{tabular}

Thirteen patients in the 24-dose group had a total of 3 or more consecutive negative smears, though only half of these were also classified as having clinically inactive disease.

The criteria used by the Bombay Leprosy Project for discontinuation of multidrug therapy require that 3 consecutive sets of skin smears (from at least 4 sites at monthly intervals) are negative in addition to clinical inactivity. Therefore, only $7(14 \%)$ patients out of 51 would stop treatment, but 6 others may be considered if the subjective nature of clinical assessment were taken into account.

Only one case in the 12-dose group had 3 consecutive negative smears.

\section{Histopathological Assessment}

A total of 60 -skin biopsies were taken for histopathological assessment. The results are shown in Table 5 (a) and (b).

One case in the 12-dose group was histopathologically inactive while $18(44 \%)$ patients were inactive after 24 doses with only $2(5 \%)$ patients still active.

Table 5

\begin{tabular}{|c|c|c|c|c|}
\hline $\mathrm{BI}$ & $\begin{array}{c}\text { Total no. } \\
\text { of cases }\end{array}$ & Active & Regressing & Inactive \\
\hline \multicolumn{5}{|c|}{ (a) 12-dose group } \\
\hline$<2$ & 5 & 4 & 1 & 0 \\
\hline$\geqslant 2$ & 14 & 1 & 12 & 1 \\
\hline Total & 19 & $5(27 \%)$ & 13 & $1(5 \%)$ \\
\hline \multicolumn{5}{|c|}{ (b) 24-dose group } \\
\hline$<2$ & 12 & 1 & 3 & 8 \\
\hline$\geqslant 2$ & 29 & 1 & 18 & 10 \\
\hline Total & 41 & $2(5 \%)$ & 21 & $18(44 \%)$ \\
\hline
\end{tabular}


However, only 2 of those found histologically inactive had 3 negative smears and neither of these had been classified as clinically inactive.

In the 24-dose group, out of 8 clinically active cases only 2 were showing activity in histopathology. The rest were showing histopathological regression.

Five (14\%) out of 37 smear negative cases were showing histopathological activity.

\section{Comment}

This was a field-based study with limited facilities and expertise. This undoubtedly accounts to a large extent for the poor correlation between the clinical, bacteriological and histopathological assessments.

However, most leprosy control programmes have to work under similar conditions and the various forms of assessment will be subject to the same observer error. Therefore, in view of the discrepancy between different methods of assessing disease activity, perhaps the main emphasis in the criteria for discontinuing therapy should be the bacterial index in smears which is the least subjective test.

Despite the limitations of this study we consider that these preliminary results are encouraging. Large numbers of multibacillary patients are rendered smear negative after 2 years of multidrug therapy.

Long-term follow-up studies on a larger scale are obviously required for a more accurate assessment of the efficacy of MDT. This would also allow estimates to be made of the number of patients relapsing during, and after stopping, drug therapy.

\section{Acknowledgments}

We are grateful to the paramedical workers, especially Mr D D Naik of BLP and student volunteers Mr Raju Vartak of RRE Society of The Acworth Leprosy Hospital for their invaluable help in this study.

\section{References}

1 WHO Study Group. Chemotherapy of Leprosy for Control Programmes. Technical Report Series No. 675, 1982.

2 Indian Association of leprologists (1982). Proceedings of the Consensus on treatment regimens in leprosy and problems of drug delivery. Ind J Lepr, 1984; 56-158.

${ }^{3}$ Ganapati, R, Revankar, CR, Gawade, PB. MDT for Multibacillary Leprosy-Experience in Bombay, 1984.

${ }^{4}$ WHO. A Guide to Leprosy Control, 26-27, 1980.

5 Ridley, D. Skin Biopsy in Leprosy, Documenta-Geigy, Ciba-Geigy, Basel, 1977.

Proceedings of the 12th International Leprosy Congress, New Delhi, February 1984; 225. 